\title{
奈良時代の石山寺仏堂における 屋根造作に関する研究
}

\section{ROOF CONSTRUCTION IN ISHIYAMADERA-TEMPLE DURING NARA PERIOD}

\author{
小野緋呂美—— $* 1 \quad$ 高田圭祐 — $* 2$ \\ 小岩正樹 — * 3 \\ キーワード : \\ 日本古代，奈良時代，建築生産，石山寺，復元，屋根
}

Keywords:

Ancient Japanese, Nara period, Architectural production, Ishiyamadera-temple, Restoration, Roof

$\begin{array}{ll}\text { Hiromi ONO } & * 1 \\ \text { Masaki KOIWA- } & * 3\end{array}$

The documents about the construction of Ishiyamadera-temple during the Nara period still exist, and the restoration research of the main hall has been examined. This paper focused on rafters and angle rafter and tried to restore the roof by examining document and drawing. The grade can be calculated from the dimensions of the listed rafter, and the advanced estimation of the material used for the main hall. As a conclusion, it is thought that the roof type was a hipped roof, and discovered the process of construction in ancient periods.

\section{1.はじめに}

正倉院文書に残る天平宝字 5 年から 6 年 (761-762) にかけて行 われた石山寺の拡張造営を記録した造石山寺所関係文書は部材寸法 や工人記録、帳簿等の古代における建築生産に関わるあらゆる記録 が残存している貴重な資料群である。この資料から奈良時代におけ る石山寺の復元研究を進めることは古代建築技術の解明への一助と なり、同時代遺構の復元研究の手立てとなると考える。

奈良時代における石山寺拡張造営の中でも仏堂注 ${ }^{1)}$ に関する研究 は、福山敏男氏によって平面形式、柱径、屋根形式等の全体の復元 研究がなされたが、屋根形式に関しては桁行五間・梁間二間の旧 堂から身舎の屋根が庇の屋根と分かれた屋根形式への変更である としている注2)。その後、茅負検討往3) によって、身舎の屋根が庇の 屋根と分かれた屋根形式は䛊った指示であり、良弁による改作指 示があったことから旧堂 $\rightarrow$ ( 庇の屋根と分かれた屋根形式の作堂指 示) $\rightarrow$ 新屋根となったことが明らかとなっている。

本稿は部材検討が進んでいない垂木、隅木を中心とする屋根部材 の一部を文書及び作図によって検討することにより、完成した奈良 時代における石山寺仏堂の屋根造作の復元を試みるものとする。

尚、本稿における文書読解は、岡藤良敬著『日本古代造営史料の 復原研究一造石山寺所関係文書・史料篇』(法政大学出版局、1985 年 3 月刊 ) を基に行っている。同書内の本文翻刻においては東京大 学史料編纂所編『大日本古文書 編年之部』に収録されている史料 を基にしているため、用した文書には岡藤氏による資料名のほか、 大日本古文書所收頁・編成別 (表中の所在、一部注釈) を記載した。

\section{2. 軒の出に関する検討}

隅木長さの検討をするにあたり、軒の出の長さが必要なため、茅 負の復元研究による軒の出の検討を行なった。軒の出の検討に当 たっては茅負検討注3) を基に、継手長さの検討を加えることで軒の 出を算出した。

茅負の長さは継手を考慮しないと桁行 88 尺、梁行 57 尺となるが、 古代の継手に関して、唐招提寺金堂の頭貫は相欠で平均当初尺 1.3 尺、唐招提寺講堂の析は鎌継 0.9 尺となっており、継手はおおよそ 1 尺と考えられる。この継手を考慮すると、桁行 85 尺梁行 55 尺 となり、どちらも軒の出 (庇柱芯から茅負端部まで、図 2 参照) は 7.5 尺 $($ 桁行 $(85-70) / 2=7.5$ 、梁行 $(55-40) / 2=7.5)$ と推測される。

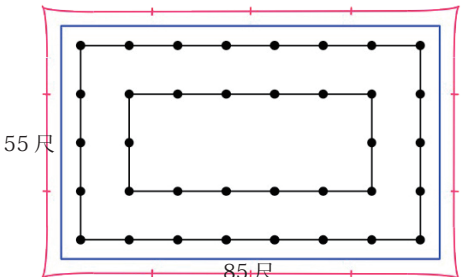

図 1 継手を考慮した場合の長さ

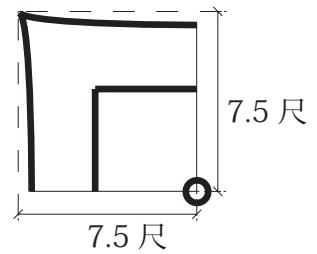

図 2 軒の出長さ

\section{3. 正倉院文書における検討}

本稿では、正倉院文書に残る造石山寺所関係文書として作材指示 が記載されている「公文案帳」注4)、材の制作及び運搬記録である 「田上山作所告朔解」注 4)、作材記録のまとめである「造石山寺告朔 解案 (春季告朔)」注 4 )「造石山院所解案 (秋季告朔)」注 4 、収納記

\footnotetext{
*1 早稲田大学大学院創造理工学研究科 修士課程 - 学士 (建築)

( ₹ 169-8555 東京都新宿区大久保 3-4-1)

早稲田大学大学院創造理工学研究科 博士後期課程 - 修士 (建築)

${ }^{*} 1 \quad$ Master Student, Graduate School of Creative Science \& Engineering, WASEDA Univ., M. Architecture

*2 Doctoral Student, Graduate School of Creative Science \& Engineering, WASEDA Univ., M. Architecture

早稲田大学理工学術院 准教授・博士 (工学)

3 Assoc. Prof., Faculty of Science and Engineering, WASEDA Univ., Dr. Eng.
} 
録である「雑材并桧皮和炭納帳」注4) を中心に材の選定を行う。以降、 表上部に特記無き限りは 5 点の文書から引用した。

\section{3-1. 隅木に関する検討}

隅木は文書において「角木」と表され主 5)、5種の材が確認され る (表 1 )。しかし、2 材 (隅木 4、5) は秋季告朔の「迴漕」での み出ている材であり、石山寺まで運ばれた記載がないため、隅木 1 - 3 の 3 種の材での検討を行う。

\begin{tabular}{|c|c|c|c|c|c|c|c|c|}
\hline 番号 & & & +) & 形状 & 数量 & 作材指示日 & 収納日 & 所在 \\
\hline 木 1 & 20 & 8 & 1 & & $\frac{12}{4}$ & $\begin{array}{l}\text { 日付不明 (正月 } \\
\text { 告朔に記載有) }\end{array}$ & 4 月 29 日 & $\begin{array}{r}5-91 \\
15-28 \\
\end{array}$ \\
\hline 隅木 2 & 21 & 6 & 5 & & 4 & 2月 8 日 & 記載なし & $15-15$ \\
\hline 隅木 3 & 24 & 7 & 5.5 & 5 尺 & 4 & 3月 16 日 & 3 月 24 日 & \begin{tabular}{|l|}
$15-168$ \\
$15-273$ \\
\end{tabular} \\
\hline 木 4 & 21 & 7 & 6 & & 5 & 不明 (廻漕 $\sigma$ ) & 記載有 ） & $5-263$ \\
\hline 木 5 & 15 & 7 & 6 & & 1 & 不明 (迴漕 $\sigma$ & 記載有) & $5-263$ \\
\hline
\end{tabular}

工程による隅木の作材時期の検討を行うため、石山寺の造営記録 をまとめたものが表 2 である。

表 2 石山寺の造営記録 (公文案帳を基に作成)

\begin{tabular}{|c|c|c|}
\hline 日付 ( 天平宝字 6 年 ) & 内容 & 所在 \\
\hline 2月8日 & 仏堂用柱・桁の作材指示 & $15-151$ \\
\hline 3月10日 & 仏堂着工 & $15-156$ \\
\hline 3月13日 & 身舎柱の柱立て完了 & $15-166$ \\
\hline 3月16日 & 「飛炎棉㭲」10 材の作材指示 & 15-168 \\
\hline 3月17日 & 石山寺に良弁着 & $15-168,169$ \\
\hline 3月19日 & 良弁による棉梠の改作指示 & $15-170$ \\
\hline 3月21日 & 棉梈 4 材追加作材指示 & $15-171$ \\
\hline 3月30日 & 棉和 14 材収納 & $15-275$ \\
\hline 4月中旬 & 屋根檜皮莫完了 & 注 6 \\
\hline
\end{tabular}

仏堂の造営は天平宝字 6 年 3 月から始まり、8月には完成してい た。また、4月中旬には檜皮草が完了していることから 3 月中には 隅木は取り付けてあったと推測できる。ここから、隅木 1 は収納日 が 4 月 29 日であり、檜皮莫が終わった後の収納となる為、仏堂以 外の作材と考えられる。

また、柱と同日に指示されている長 21 尺 4 枝の隅木 ( 隅木 2) はこの記録以降登場しないため、使用されているかは確定できない。 長 24 尺 4 枝 (隅木 3 ) は 3 月 16 日に作材指示が行われ、寺家ま で運ばれた記録もあるため、使用された可能性が高い。2月 8 日及 び3月 16 日の作材指示記録では、どちらも仏堂に使うための材と 記載されているが、3月 19 日の良弁による屋根形式の改作指示前

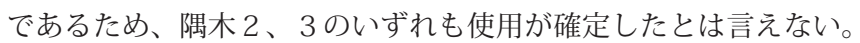

この文書検討から仏堂隅木の作材の種類として 1)身舎の屋根が庇の 屋根と分かれた屋根形式を想定した材、(2)新屋根を想定した材の 2 種があることが判明した。

以上より、この 2 種 8 枝 ( 隅木 $2 、 3$ ) 及び旧堂の隅木 4 枝を候 補材として検討を行う。

\section{3-2. 垂木に関する検討}

文書において、垂木は「架」と記載され注5)、棉梠 (木負、茅負 を指す注5) $)$ の構成から二軒と考えられるが、文書には地垂木、飛 檐垂木の区別はない。

5つの文書より、垂木は反り違いも含めた 10 種が確認され、 (表 3 ) 長さとしては 24 尺、16 尺、15 尺、12 尺、11 尺、10 尺、9 尺が挙げられる。地垂木長さは、端部の想定を行うため木負長さ の検討を行いたいが、旧材が使われている注3) とされており、ここ での検討は不可能である。文書に戻り、天平宝字 6 年 2 月 28 日

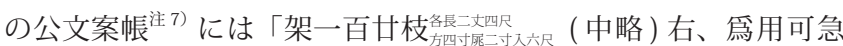
作五丈殿架」の記載があることから 24 尺材 (垂木 1、2) は五丈殿 の材と考えられる。よって仏堂の垂木候補材は 16 尺材、15 尺材、 12 尺材、11 尺材、10 尺材、9 尺材 (垂木 3-10) が考えられる。また、 表 3 の垂木 3-10 の作材指示日をみると、3/16,3/21,3/30 となっ ており、隅木の指示記録とも近い日程で作材指示をしていることが わかる。

天平宝字 6 年 3 月 16 日の公文案帳 ${ }^{81}$ 8) を見ると、「一架六十枝 务長一坛尺」が隅木 24 尺材 4 枝と同時に作材指示されていることが わかり、「仏堂用度如件」と書かれていることから仏堂の垂木とし て 15 尺材が作材されていたことがわかる。しかし、この指示は 3 月 19 日の屋根改作指示以前で あり、15 尺材が実際に仏堂に 使われたかは不明である。また、 9 尺材、11 尺材は 8 枝、10 尺 材は 12 枝、12 尺材は 4 枝 ( 3 本収納 ) を作材指示し、収納さ れている。これらは本数の点か ら隅の垂木 (図 3 イ) と考えら れ、この 4 種の材は隣接してい

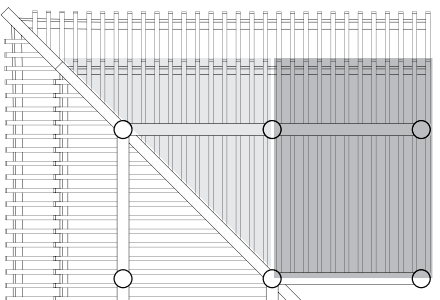

ア：身舎柱間に入る地垂木 イ: 隅に入る地垂木

図 3 垂木名称凡例
よって、身舎柱間に入る地垂木 (図 3 ア ) は 15 尺材、16 尺材の 2 通りが考えられる。 表 3 垂木の記載一覧 (日付は全て天平宝字 6 年)

\begin{tabular}{|c|c|c|c|c|c|c|c|c|}
\hline 番号 & $\begin{array}{l}\text { 長 } \\
\text { ( 尺) }\end{array}$ & $\begin{array}{l}\text { 幅 } \\
\text { (寸) }\end{array}$ & $\begin{array}{l}\text { 丈 } \\
\text { (寸) }\end{array}$ & 形状 & $\begin{array}{l}\text { 数量)作材指示日 } \\
\text { (枝)(数量 (枝): 日付) }\end{array}$ & $\begin{array}{l}\text { 収納日 } \\
\text { (数量 (枝): 日付) }\end{array}$ & 特記事項 & 所在 \\
\hline 垂木 1 & 24 & 4 & 4 & 6尺入㞑 3寸 & $662 / 28$ & $34: 3 / 30,9: 5 / 10,15: 5 / 16,8: 5 / 19$ & 五丈殿の材 & 15-155,285,286 \\
\hline 垂木 2 & 24 & 4 & 4 & 6尺入庣 2寸 & \begin{tabular}{l|l}
65 & $2 / 28$
\end{tabular} & $6: 3 / 8,40: 3 / 15,13: 3 / 20,6: 3 / 24$ & 五丈殿の材 & $15-155,267 \sim 273$ \\
\hline 重木 3 & 16 & 3 & 3 & 康3寸 & 60 記載なし & $60: 4 / 29$ & & $15-284$ \\
\hline $\begin{array}{ll}\text { 垂木 } 4 \\
\end{array}$ & 16 & 3 & 3 & 直 & 140 記載なし & $140: 4 / 29$ & & $15-284$ \\
\hline 重木 5 & 16 & 3 & 3 & 直 & $11330: 3 / 21$ & $10: 2 / 7,29: 2 / 23,63: 3 / 2,12: 3 / 30$ & & $15-171,263 \sim 275$ \\
\hline $\begin{array}{l}\text { 重木6 } \\
\end{array}$ & 15 & 3 & 3 & 直 & \begin{tabular}{l|l}
88 & $60: 3 / 16 、 19: 3 / 30$
\end{tabular} & $\begin{array}{l}38: 3 / 24 、 22: 3 / 30 、 22: 4 / 5,3: 4 / 22 、 \\
3: 5 / 2\end{array}$ & & $15-168,178,273 \sim 285$ \\
\hline \begin{tabular}{l|l} 
重木 7 \\
\end{tabular} & 12 & 3 & 3 & 直 & \begin{tabular}{l|l}
3 & $4: 3 / 30$
\end{tabular} & $3: 4 / 5$ & & $15-178,15-281$ \\
\hline 重木 8 & 11 & 3 & 3 & 直 & \begin{tabular}{l|l}
8 & $8: 3 / 30$
\end{tabular} & $8: 4 / 5$ & & $15-178,15-281$ \\
\hline 重不 9 & 10 & 3 & 3 & 直 & $1212: 3 / 30$ & $12: 4 / 5$ & & $15-178,15-281$ \\
\hline 重木 10 & 9 & 3 & 3 & 直 & \begin{tabular}{l|l}
8 & $8: 3 / 30$
\end{tabular} & $8: 4 / 5$ & & $15-178,15-281$ \\
\hline
\end{tabular}




\section{3-3. まとめ}

以上の文書検討から、隅木候補材は長 21 尺材 4 枝、長 24 尺材 4 枝の 2 種 (隅木 $2 、 3$ ) と旧材、垂木は身舎柱間に入る地垂木候 補材が長 15 尺材方 3 寸、長 16 尺材方 3 寸9 2 種 (垂木 3-6) と旧材、 隅の垂木は長 12 尺材、11 尺材、10 尺材、9 尺材 (いずれも方 3 寸) の 4 種 (垂木 7-10) が選定された。続いて作図検討をすることによっ て材を選定する。

\section{4. 作図検討}

\section{4-1. 地垂木勾配に関する検討}

石山寺仏堂では前述した垂木 に関する文書検討より長 9 尺 材、10 尺材、11 尺材、12 尺 材の垂木は隣接していると仮定 できる。ここから地垂木勾配を西 算出し、隅木長さを求める検討 を行いたい。

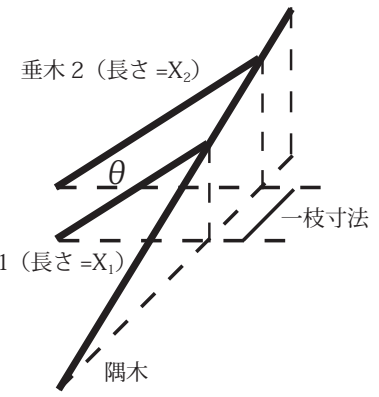

まず、地垂木勾配の算出方法 四 4 隣接する垂木長と勾配、一枝寸法 を検討する。隣り合う二本の 垂木の長さを $\mathrm{X}_{1} 、 \mathrm{X}_{2}$ とする と、それぞれの正射影の長さ $\left(\mathrm{X}_{1} \cos \theta 、 \mathrm{X}_{2} \cos \theta\right)$ の差が 一枝寸法に当てられる (図 4、 5)。

よって、(一枝寸法) $=\mathrm{X}_{2} \cos$ $\theta-\mathrm{X}_{1} \cos \theta=\left(\mathrm{X}_{2}-\mathrm{X}_{1}\right) \cos \theta$ と 表すことができる。

また、表 4 の参照遺構注 ${ }^{91}$ の垂

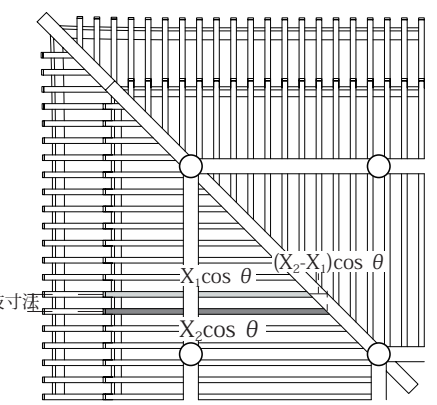

図 5 隣接する垂木長と一枝寸法の関係 木勾配より、地垂木勾配が 4 寸 5 分から 5 寸勾配を取り、その時 の $\cos \theta$ の值は 0.9 近傍を取ることがわかる。

一枝寸法から地垂木勾配を計算 するにあたり、

柱間一間 /一枝寸法 = 完数…1 を用いることが必要である。 隅では誤差が生じる可能性があ

表 4 参照遺構の垂木勾配
\begin{tabular}{|l|r|r|} 
選定建物 & 地垂木勾配 & $\cos \theta$ \\
\hline 新薬師寺本堂 & 4寸 5 分 & 0.91 \\
\hline 唐招提寺金堂 & 5 寸 & 0.89 \\
\hline 唐招提寺講堂 & 4 寸 5 分 & 0.91 \\
\hline
\end{tabular}
るため、柱間一間で算出した值を用いる。

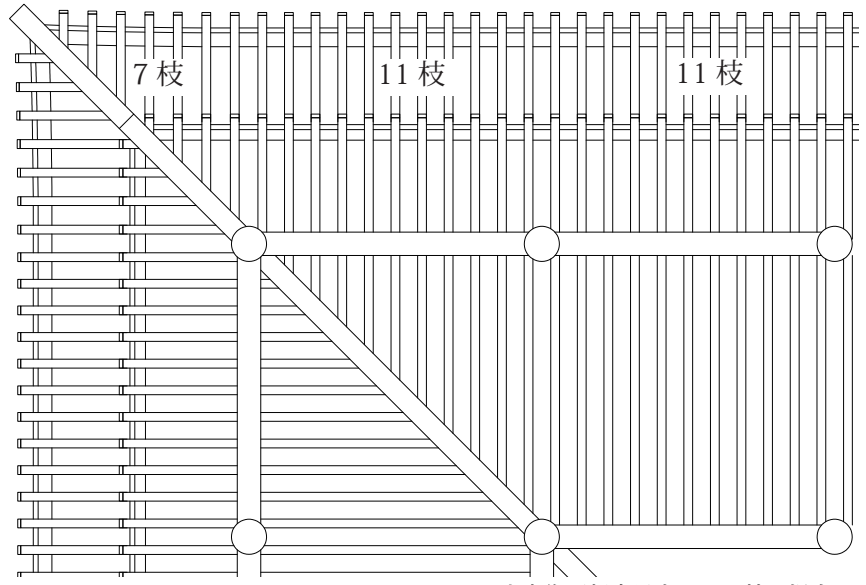

図 6 石山寺復原想定見上図 (11 枝の場合)
(1)式:

石山寺仏堂では柱間は 10 尺であり、この時、結果を完数值とし、 且つ $\cos \theta$ が 0.9 尺近傍を取り、一枝寸法が 0.9 尺〜 1 尺程度とす ると、柱間に入る垂木は 10 枝または 11 枝となる。

【10 枝の場合】

$\left(\mathrm{X}_{2}-\mathrm{X}_{1}\right) \cos \theta=$ 一枝法 1.1 尺 $\times 0.9090=1$ 尺

柱間 $/$ 一枝寸法 $=$ 完数 $\quad 10 / 1=10$

【1 1 枝の場合】

$\left(\mathrm{X}_{2}-\mathrm{X}_{1}\right) \cos \theta=$ 一枝寸法 1 尺 $\times 0.9090=0.9090$ 尺

柱間 $/$ 一枝寸法 $=$ 完数 $\quad 10 / 0.9090=11$

どちらの場合でも $\cos \theta=0.9$ 近傍となり、地垂木勾配は 4 寸 6 分勾配となり、表 4 と比べても妥当である。

また、(庇柱から茅負までの長さ)/一枝寸法＝完数の関係、隅木 広さを用いて作成した見上図の一部が図 6 である。この図により、 隅の一枝寸法 1.071 尺、枝数 7 が想定される。

地垂木勾配を利用し、隅木長さを算出するため、地垂木、庇柱、 木負の関係を整理する。

隅の飛檐垂木が 7 枝であることから、地垂木は枝数 4 または 5 枝が 想定される。(図 7)

・ 4 枝のとき

(木負から庇柱 までの長さ) = 4.28 尺

・ 5 枝のとき (木負から庇柱 までの長さ) = 5.36 尺

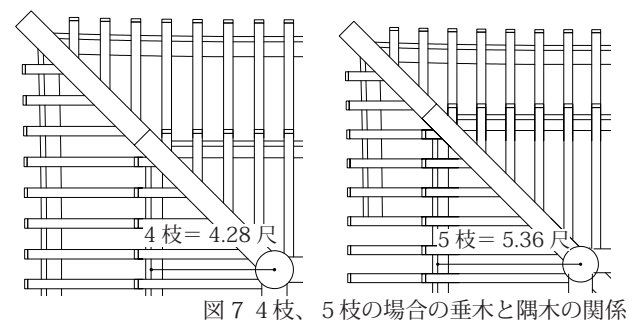

\section{4-2. 隅木の作図検討}

4-2-1. 地隅木の検討

・4 枝のとき (図 8)

地垂木長さは、

(10+4.28)/0.909=15.71 尺となる。一枝寸法は地垂木勾配から算 出しているので、地垂木公配 0.459 を用いると、14.28 尺に対し、6.55 尺上がる。

この高さを隅木勾配として用いる と、

$$
\sqrt{14.28 \sqrt{2}^{2}+6.55^{2}}=21.17
$$

21.17 尺となり、24 尺材が妥当と 考えられる。
図 84 枝の場合の垂木と隅木の関係 (単位は全て尺)

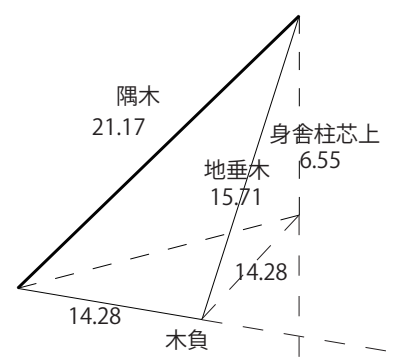


・5枝のとき (図 9)

地垂木長さは、

(10+5.36)/0.909=16.90 尺となる。

地垂木勾配 0.459 を用いて、

15.36 尺に対し、7.05 尺上がる。

この高さを隅木勾配として用いる

と、

$$
\sqrt{15.36 \sqrt{2}^{2}+7.05^{2}}=22.77
$$

22.77 尺となり、 24 尺材が妥当と

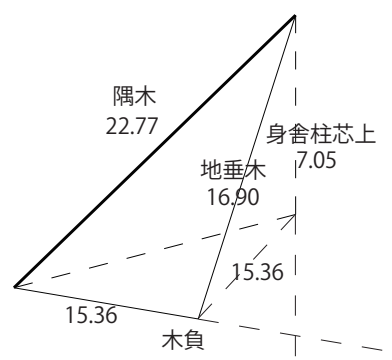

図 95 枝の場合の垂木と隅木の関係 (単位は全て尺)
考えられ、4 枝、5 枝ともに地隅木は 24 尺材が適切であると考え られる。

\section{4-2-2. 飛檐隅木の検討}

断面寸法の妥当性による検討を行う。地隅木を 24 尺材とした場 合、飛檐隅木には 21 尺材または旧材 (14 尺以上) が使用されるこ ととなり、

地隅木 24 尺材 (広 7 寸厚 5 寸半) 一飛檐隅木 21 尺材 (広 6 寸厚 5 寸) 地隅木 24 尺材 (広 7 寸厚 5 寸半) 一飛檐隅木旧材

の組み合わせが考えられる。

隅木の断面寸法においては広さ (幅) が変わることは考えづらく、 また 21 尺材の納入記録がないことからも使用の可能性は低いため、 飛檐隅木は旧材を利用したと考えられる。

\section{4-2-3. 隅木からみた屋根形式の考察}

地隅木 24 尺を用いて屋根形式の検討を行う。

寄棟造では二本の隅木が梁筋上にくることが村田氏注9) によって 指摘されており、今回の場合、28 尺以上が適する。この場合、24 尺材の他に材を継いだと考えられるが、地隅木に継いだ材の記録は 見つからなかった。入母屋造の場合、作図上は 24 尺材単独で使わ れたと言え適する。

表 5 破風の記載一覧 (日付は全て天平宝字 6 年)

\begin{tabular}{|c|c|c|c|c|c|c|c|c|}
\hline 橎号 & $\begin{array}{l}\text { 長 } \\
\text { ( 尺) } \\
\end{array}$ & $\begin{array}{l}\text { 厚 } \\
\text { (寸) } \\
\end{array}$ & \begin{tabular}{|l} 
広 \\
$($ 寸 $)$
\end{tabular} & 形状 & $\begin{array}{l}\text { 数量 } \\
\text { (枝) }\end{array}$ & $\begin{array}{l}\text { 作材指示日 } \\
\text { (数量：日付) } \\
\end{array}$ & $\begin{array}{l}\text { 収納日 } \\
\text { (数量：日付) }\end{array}$ & 所在 \\
\hline \begin{tabular}{|l|} 
破風 1 \\
\end{tabular} & 24 & 5 & 8 & 6尺入テウ 3寸 & 4 & $4: 2 / 28$ & $3: 3 / 24,1: 5 / 16$ & $15-155,273,286$ \\
\hline 破風 2 & 20 & 4 & 7 & 直 & 4 & 記載なし & $4: 3 / 20$ & $15-271$ \\
\hline 破風 3 & 17 & 4 & 9 & 記載なし & 4 & 記載なし & $2: 3 / 2,2: 3 / 8$ & $15-266,267$ \\
\hline 破風 4 & 16 & 4 & 6.5 & 4尺入テウ 3寸 & 4 & $4: 3 / 4$ & $4: 3 / 20$ & $15-158,271$ \\
\hline \begin{tabular}{|l|} 
破風 5 \\
\end{tabular} & 12 & 2.5 & 6 & 記載なし & 4 & $4: 4 / 7$ & $4: 4 / 22$ & $15-184,281$ \\
\hline
\end{tabular}

しかし、入母屋造を想定した場合、破風の使用がある。表 5 は破 風の記録一覧である。このうち、屋根の改作指示である 3 月 19 日 以降に納入され、5-1. に記述するように屋根亘が 4 月上旬に始ま ると想定できるので 20 尺及び 16 尺の 2 種が考えられる。しかし、 20 尺材は直材であるため入母屋造の破風とは考え難い。また 16 尺材は指示日が改作指示前で、収納が改作指示翌日であることから 仏堂で使われた可能性が低いと考えられる。

よって入母屋造の可能性は低く、寄棟造を想定して検討を進める。

\section{4-3. 垂木に関する検討}

\section{4-3-1. 地垂木に関する検討}

4-2-1. での地隅木、地垂木の模式図検討より、庇柱から先の地垂 木が 4 枝の場合は 15.71 尺、 5 枝の場合は 16.90 尺が最低でも必 要である。(図 7、8) 候補材は 15 尺材または 16 尺材であるため、 庇柱から先の地垂木が 4 枝が適当と考えられ、16 尺材が身舎柱間 に入る地垂木と作図検討では考えられる。

\section{4-3-2. 飛檐垂木に関する検討}

飛檐垂木の検討を行うにあたり、遺構を元に垂木の端点および長 さを算出する。表 6 は同時代における垂木寸法の一覧である。

このうち、復原矩計図のあった唐招提寺講堂の垂木長さを実測し たところ、

(地垂木) 18.48 尺（飛檐垂木）9.99 尺

となる。地垂木は 柱間一間の違いか ら長さの検討に大 きく差が出ている が、身舎柱上まで きていることに重 点を置き、先の作

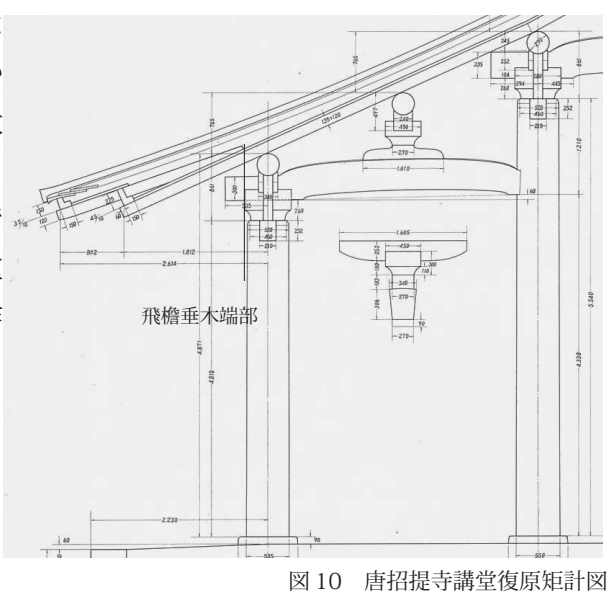

表 6 同時代遺構の垂木寸法、垂木配置

\begin{tabular}{|c|c|c|c|c|c|c|c|}
\hline 建物名 & 建立年代 & 平面形式 & 屋根形式 & 垂木 & 地垂木 & 飛檐垂木 & 一枝寸法 \\
\hline 法隆寺金堂 & 670 年代 & $\begin{array}{l}\text { 初重身舎三間二間 (高麗尺 } 9 \text { 尺)、庇高麗尺 } 6 \text { 尺、 } \\
\text { 上重析行中央二間 (高麗尺 } 8.622 \text { 尺)、梁行中央間 } \\
\text { ( 高麗尺 } 8.25 \text { 尺)、隅間 (高麗尺 } 8.25 \text { 尺) }\end{array}$ & $\begin{array}{l}\text { 二重 }(\text { 上 } \\
\text { 重入母屋 } \\
\text { 造 })\end{array}$ & $\begin{array}{l}\text { 角垂木 } \\
\text { 平行 } \\
\text { 軒 }\end{array}$ & $\begin{array}{l}\text { 高 } 4.8 \text { 寸 } \\
\text { 厚 } 4 \text { 寸 }\end{array}$ & なし & 高麗尺 7.5 尺 \\
\hline $\begin{array}{l}\text { 法隆寺食堂及 } \\
\text { び細殿 }\end{array}$ & 奈良時代 & 桁行天平尺 70 尺、梁間 32 尺 & 切妻造 & 二軒 & $\begin{array}{l}\text { 高 } 4 \text { 寸 厚 } \\
3.9 \text { 寸 }\end{array}$ & $\begin{array}{l}\text { 高 } 3.4 \text { 寸厚 } \\
3.1 \text { 寸反有 }\end{array}$ & 記載なし \\
\hline 新薬師寺本堂 & $\begin{array}{l}\text { 天平 } 19 \text { 年 }(747) \\
\text { ごろ }\end{array}$ & 桁行七間梁間五間、桁行中央間 16 尺、他 10 尺 & 入母屋造 & 二軒 & 円垂木 & 角垂木 & 当初尺 1 尺 \\
\hline 東大寺法華堂 & $\begin{array}{l}\text { 天平勝宝元年 } \\
(749) \text { 以前 }\end{array}$ & $\begin{array}{l}\text { 正面八間側面五間、身舎正面三間 } 14 \text { 尺、側面 } 12 \text { 尺、 } \\
\text { 庇 } 10 \text { 尺 }\end{array}$ & 入母屋造 & $\begin{array}{l}\text { 記 載な } \\
\text { し }\end{array}$ & 記載なし & 記載なし & 9.4 寸 \\
\hline $\begin{array}{l}\text { 法隆寺東院伝 } \\
\text { 法堂 }\end{array}$ & $\begin{array}{l}\text { 天平宝字 } 5 \text { 年 } \\
(761) \text { 以前 }\end{array}$ & $\begin{array}{l}\text { 身舎七間庇二面、枌行 (東より 1,4,5 間) } 11.74 \text { 尺 } \\
\text { 他 } 11.825 \text { 尺、梁間 } 8.805 \text { 尺 ( 天平尺 } 9 \text { 尺) }\end{array}$ & 切妻造 & 二軒 & $\begin{array}{l}\text { 高 } 4 \text { 寸厚 } \\
3.7 \text { 寸反有 }\end{array}$ & 記載なし & 記載なし \\
\hline 唐招提寺講堂 & $\begin{array}{l}\text { 天平宝字 } 4,5 \text { 年 } \\
(760,761) \text { ごろ }\end{array}$ & $\begin{array}{l}\text { 正面九間側面四間、身舎一間平均 } 0.98 \times 13 \text { 尺、 } \\
\text { 庇 } 0.98 \times 11.2 \text { 尺 }\end{array}$ & 入母屋造 & 二軒 & $\begin{array}{l}\text { 高 } 4.4 \text { 寸 } \\
\text { 厚 } 4 \text { 寸 }\end{array}$ & $\begin{array}{l}\text { 高 } 4.4 \text { 寸厚 } \\
4 \text { 寸 }\end{array}$ & $\begin{array}{l}\text { 桁 } 0.98 \text { 尺、梁中央 } \\
1.11 \text { 尺、隅 } 1.16 \text { 尺 }\end{array}$ \\
\hline 唐招提寺金堂 & $\begin{array}{l}\text { 宝亀年間 (770- } \\
781)\end{array}$ & $\begin{array}{l}\text { 身舎五間四面、桁行中央間 } 16 \text { 尺両隣 } 15 \text { 尺身舎端 } \\
\text { 間 } 13 \text { 尺庇 } 11 \text { 尺、梁間身舎一間 } 13.5 \text { 尺庇 } 11 \text { 尺 }\end{array}$ & 寄棟造 & 二軒 & $\begin{array}{l}\text { 円、 } 4.6- \\
5 \text { 寸 }\end{array}$ & 直 & 当初尺 1 尺 \\
\hline
\end{tabular}


図検討を重視する。飛檐垂木においては、内側の端部の位置の決定 によって長さが決定されているととらえることができる。

唐招提寺講堂 (図 10) の場合は、大斗端で規定していると考えら れ、長さのみを考慮すると、9.99 尺という值をとっており、9 尺材、 10 尺材が適する值ではあるが本数の点からもこれらが使われた可 能性は低く、旧材、または 15 尺以上の収納材を加工して使用した と考えられる。

\section{5. 垂木の本数に関する検討}

5-1. 他材の記録による工程検討

「雑物用帳」注4）より釷の納入記録を見ると、3月 24 日から 4 月 2 日まで断続的に「庇架」用の釷が納入されていることがわかる。 注 11) この庇架は、庇部分に取り付ける垂木と考えると、地垂木のこ とと想定できる。また、4月 6 日は「架」の釘と記載され、区別は つけられていないため地垂木及び飛檐垂木両方のことを指す可能性 が指摘できる。以上より 3 月 24 日から 4 月 6 日近辺で垂木の取り 付けが行われた可能性が指摘でき、表 3 の 16 尺材 (垂木 5 ) の収 納日が隅の地垂木 (垂木 7-10) の収納日より早いことからも身舎柱 間に入る地垂木 $\rightarrow$ 隅の地垂木の順で取り付けられたと考えられる。

次に同文書より檜皮及び黒葛の納入記録を見ると、3 月 28 日に 仏堂の黒葛の納入が始まり、4月 10 日まで断続的に続く。 ${ }^{\text {注 }}{ }^{12)}$ 檜 皮に関しては仏堂と決定していないが、同時期に納入されているこ とが判明し、「公文案帳」では僧房と合わせて作材の指示も出てい ることからこの時期に屋根草が行われていると推測できる。 4 月 12 日以降からは莕の作材指示があり注 ${ }^{13)}$ 、仏堂の壁面を塗る作業 が始まると考えられ、4月 6 日から 12 日頃までに垂木は配し終わっ ていると考えられる。また、仏堂の作材指示の始妓えられる柱 は桁、隅木とともに2月8日にされており、それ以降に垂木の作材 指示及び納入がくると考えられる。

このことから 16 尺材垂木の収納記録 (表 3) を見ると、2 月 23 日 29 枝 (垂木 5 )、3 月 2 日 62 枝 (垂木 5)、3 月 30 日 12 枝 (垂 木 5) の計 103 枝が仏堂に使われた可能性が高い。垂木 $3 、 4$ は収 納日が 4/29 のため、垂木 5 のうち 10 枝は収納日が 2/7 のため、 いずれも仏堂以外の可能性が高い。また、15 尺材は 3 月 24 日に も作材指示が出ているため、仏堂に全く使われなかったという見方 は出来ないことと、隅の垂木の最長が 12 尺材 3 枝であることから 15 尺材 88 枝 (垂木 7) は隅や飛檐垂木に使われていたと推測でき る。

\section{5-2. 見上図による本数検討}

図 11 は石山寺仏堂想定見上図である。3-2-1. での地隅木、地垂 木の模式図検討を用い、12 尺材がそのまま使用できるのは木負端 部から 11 枝目までであることと 15 尺材がそのまま使用できるの が 14 枝目までであることから、材の分布は図 11 のようになった。 これにより、16 尺材は 11 枝 $\times 14$ 間 +1 枝 $\times 8$ 間 $=162$ 枝または 10 枝 $\times 14$ 枝 +1 枝 $\times 8$ 間 $=148$ 枝使用することがわかる。文書で確 認できた本数は 113 枝のため、残りは旧材の可能性が指摘できる。 また、 15 尺材は $3 \times 8=24$ 枝が使われており、文書に記載されてい た 88 枝を考慮すると、88-24=64 枝は地垂木の隅 (図 11 の地垂木
のうち、白色部分 ) 又は飛檐垂木に分割して使われたと推測できる。

\section{6. 結語}

本論考では、隅木と垂木の部材長及び形状を検討することにより、 奈良時代における石山寺仏堂の屋根造作の工程を一部復原すること ができた。今後は工程のさらなる復元のため、足庭等工人記録の復 元も進めていきたい。
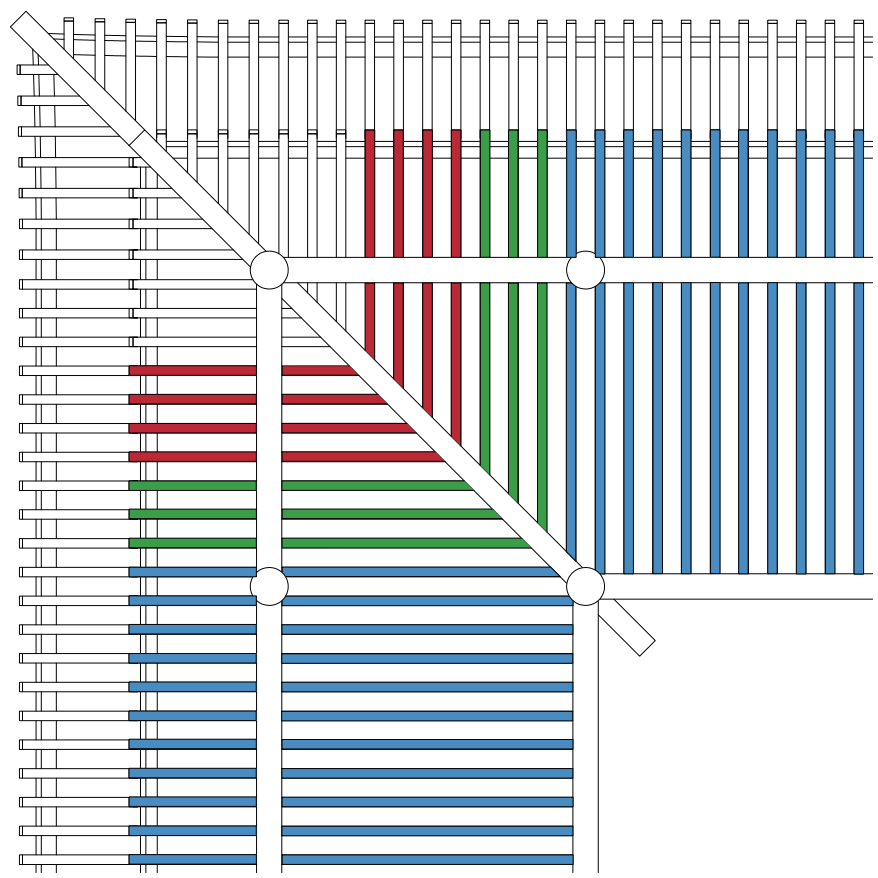

16 尺材

15 尺材 図 11 石山寺仏堂想定見上図

12-9 尺材 
1) 福山敏男 : 日本建築史の研究, 奈良時代に於ける石山寺の造営

桑名文星堂 1943.10

2) 岡藤 良敬: 造石山寺所関係文書- 史料篇, 福岡大学総合研究所報 (100),

巻頭 $\mathrm{p} 1-414,1987.03$

3) 村田健一 : 伝統建築を読み解く, 学芸出版社,2006

注

注 1 ) 本稿では原史料に合わせて石山寺本堂を仏堂と呼ぶ。

注 2 ) 福山敏男 : 日本建築史の研究, 奈良時代に於ける石山寺の造営

桑名文星堂 1943.10

注 3）小岩正樹：良弁の石山寺造営における改作指示について, 日本建築学

会学術講演梗概集 F2,pp.645-646, 2011

注 4 ) 石山寺文書研究は、福山氏が発端となり、その後を受けて岡藤氏によっ

て基礎的研究は果たされている。今回は岡藤 良敬「造石山寺所関係文書・

史料篇」を用い、正倉院文書の読解とした。以下の表が「造石山寺所関係文

書・史料篇」に記載された資料名、日付、概要である。

表「造石山寺所関係文書・史料編」内容一覧

\begin{tabular}{|c|c|c|c|c|}
\hline 章 & 史料名 & 年月 & 概要 & 所在 \\
\hline 1 & 田上山作所告朔解 & 天平宝字 6.1-6.4(月 1) & \begin{tabular}{|l|} 
田上山作所にお括作材、運材、雑物、 \\
人物、給料の記録
\end{tabular} & $\begin{array}{l}15-344 \sim 348,5-77 \sim 83,5-114 \sim 124,5-148 \sim 160,5- \\
221 \sim 229,15-463 \sim 465\end{array}$ \\
\hline 2 & 甲賀山作所告朔解 & 天平宝字 6.1-6.4(月 1) & \begin{tabular}{|l|} 
甲賀山作所にお括作材、運材、杂倠物、 \\
人物、給料の記録
\end{tabular} & 5-86 94,5-95 102,15-462 \\
\hline 3 & 造石山寺告朔解案 (二月告朔) & 天平宝字 6.3 & $\begin{array}{l}\text { 田上山作所の } 2 \text { 月における作材、運材、 } \\
\text { 雑物、人物、給料の記録 }\end{array}$ & 5-137 139 \\
\hline 4 & 造石山寺告朔解案 (春季告朔) & 天平宝字 6.1-6.4(月 1) & $\begin{array}{l}\text { 田上山作所の春季における作材、運材、 } \\
\text { 雑物、人物、給料の記録 }\end{array}$ & 5-163 187 \\
\hline 6 & 造石山院所解案 (秋季告朔) & 天平宝字 6 . 閏 12 & $\begin{array}{l}\text { 田上山作所の秋季における作材、運材、 } \\
\text { 雑物、人物、給料の記録 }\end{array}$ & 16-186 215,219 222,227 252,15-127,5-335 354 \\
\hline 7 & 公文案帳 & 天平宝字 6.1-7.2.18 & \begin{tabular}{|l|} 
石山寺から田上山作所にあてた作材指 \\
示記録、人員配置等に関する牌
\end{tabular} & $\begin{array}{l}5-385 \sim 386,15-85,137 \sim 234,243 \sim 254,16-1 \sim 3,118 \sim 120,25- \\
246\end{array}$ \\
\hline 9 & 雑材并桧皮和炭納帳 & 天平宝字 6.15-6.7.22 & 木材、檜皮、葛等の収納記録 & 15-258 289 \\
\hline 10 & 鉄充并作上帳 & 天平宝字 6.1.16-6.8.3 & 鉄物収納記録 & 5-60 62,15-292 306 \\
\hline 12 & 雑材并桧皮和炭用帳 & 天平宝字 6.1-6.10.1 & 木材、檜皮、葛等の収納記録 & 15-365 374 \\
\hline 8 & 雑物収納帳 & 天平宝字 5.12.26-6.2.26 & その他の収納記録 & 4-537 539 \\
\hline 5 & 労劇文案 & 天平宝字 6.8.27 & 主に官人の名簿及び出勤記録 & $15-235 \sim 242$ \\
\hline 11 & 銭用帳 & 天平宝字 5.12.24-7.1.30 & 出納帳 & 4-532 536,5-355 371,15-442 452,457 460 \\
\hline 13 & 雑物用帳 & 天平宝字 6.1-6.7.27 & その他の収納記録 & 15-365 374 \\
\hline 14 & 食物用帳 & 天平宝字 6.1-6. 閏 12.29 & 食料の記録 & 5-5 22,24 30,15-43616-177 178 \\
\hline 15 & 雑様手実帳 & 天平宝字 6.3.3-6.8.9 & 雇工給料記録 & 5-220,239 240,261,15-357 364 \\
\hline
\end{tabular}

【備考】

田上山作所：滋賀県大津市南部に位置する山間部に作られた木材伐採・加工の為の施設

告朔：造東大寺司に提出するための報告書

甲賀山作所：滋賀県甲賀市に位置する山間部に作られた木材伐採・加工の為の施設。田上山作所の前に使われていた

春季：旧暦 1 月から 3 月のこと

秋季 : 旧暦 7 月から 9 月のこと

注 5）福山敏男: 正倉院文書に見える建築用語, 正倉院年報 8,1986.3

図版典拠

注 6 ）大日本古文書 15-322 326

注 7）大日本古文書 15-155

注 8）大日本古文書 15-168

注 9) 同時代 (8世紀前後)の堂うち、復元形式が判明しているものを選定した。

注 10）村田健一: 伝統建築を読み解く, 学芸出版社, 2006 を参照すると、

図 1-9,11 筆者作成

図 10 奈良県教育委員会 : 国宝唐招提寺講堂他二棟修理工事報告書,1972

表 1-6 筆者作成

[2019 年 6 月 5 日原稿受理 2019 年 8 月 20 日採用決定］ する必要上、正面側の隅木と、背面側の隅木の交点がほぼ梁筋に合う必要が あること」と指摘している。

注 11) 大日本古文書 15-320 323

注 12) 大日本古文書 15-322 326

注 13) 大日本古文書 15-326 